\title{
高温高圧下での鉄-ケイ酸塩-水系の中性子回折その場観察
}

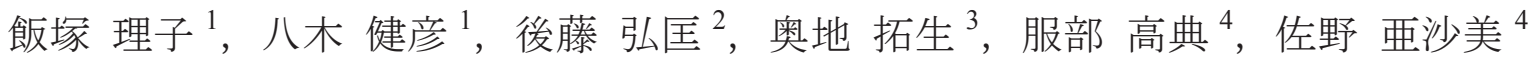

(東京大学大学院理学系研究科地殸化学実験施設 ${ }^{1}$, 東京大学物性研究所 ${ }^{2}$, 岡山大学惑星物質研究所 ${ }^{3}$, 日本原子力研究開発機構 J-PARC センター ${ }^{4}$ )

\section{In-situ Neutron Diffraction of Iron Hydride in Iron-silicate-water System under High Pressure and High Temperature Condition}

\author{
Riko Iizuka-Oku ${ }^{1}$, Takehiko Yagi ${ }^{1}$, Hirotada Gotou ${ }^{2}$, Takuo Okuchi ${ }^{3}$, \\ Takanori Hattori ${ }^{4}$ and Asami Sano-Furukawa ${ }^{4}$
}

Geochemical Research Center, Graduate School of Science, The University of Tokyo ${ }^{1}$, Institute for Solid State Physics, The University of Tokyo ${ }^{2}$, Institute for Planetary Materials, Okayama University ${ }^{3}$ and J-PARC Center, Japan Atomic Energy Agency ${ }^{4}$

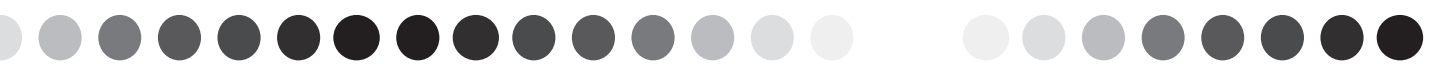

\begin{abstract}
Hydrogen is the most abundant element in the solar system and is considered to be one of the promising candidates of the light elements in the Earth's core. However, the amount of hydrogen dissolved in the core and its process are still unknown because hydrogen cannot be detected by $\mathrm{X}$ ray and easily escapes from iron at ambient conditions. In this study, we have conducted high-pressure and high-temperature in-situ neutron diffraction experiments on the iron-hydrous mineral system using PLANET in J-PARC. We observed that the water, which was dissociated from a hydrous mineral, reacted with iron to form both iron oxide and iron hydride at about $4 \mathrm{GPa}$. Iron hydride remained stable after further increase in temperature. This formation occurred at $1000 \mathrm{~K}$, where no materials melted. This suggests that hydrogen dissolved into iron before any other light elements dissolved in the very early stage of the Earth's evolution.

Keywords: Iron hydride, Hydrogen, Neutron diffraction, High-pressure experiments, Earth's evolution
\end{abstract}

\section{1.はじめに}

地球科学が専門外の読者向けに，まずは地球形 成史における鉄と軽元素の関係について書き始め たい。原始地球が形成された過程は，諸書で詳し く議論されている[例えば，1].まず隕石のような 始源物質が集積して次第に大きくなり，衝突エネ ルギーと重力エネルギーの解放により内部の温度 が上昇していった。 やがて，それらは融け始め， 重たい鉄が分離して深部へと沈み込んで核 (コア) を形成した.このようにしてできた現在のコアは， 純粋な鉄に比べて $10 \%$ 程度密度が小さいことが地 震波の観測から分かっており，コアには軽元素が 溶け込んでいると考えられている。この候補とし て, 大気圧下でも鉄との親和性が高い硫黄や炭素, 酸素，あるいは太陽系の元素存在度からケイ素な どが候補に挙げられており，様々な実験がなされ てきた。一方，水素は，太陽系の中で最も多く存
在する元素であり，地球にも水という形で大量に 含まれている。この水素は最も軽い元素であるた め，鉄に固溶した場合に微量でも密度の減少効果 は大きい，しかし，常圧下では鉄中に僅か ppm 才 ーダーでしか溶け込まず，また気体状態の水素は 地球の重力圈で保持できないために，これまでコ アの鉄に水素が溶け込むプロセスはよく分かって いなかった。

鉄と水素の反応に関して Fukai らは，高温高圧 下で鉄水素化物が生成されることを報告した[2]. また，水素の代わりにケイ酸塩と水を入れても同 様のことが起きることを明らかにし，原始地球の 形成期に集積した隕石に水分が含まれていれば, 反応してできた水素がコアに取り込まれるという シナリオを発表した。高温高圧下で試料が融ける と, 鉄は表面張力によって球形に集まり, 反応で 残ったケイ酸塩と重力分離を起こして底に沈んだ 
状態で回収される。これは地球のマントル（岩石 圈）とコアの分離プロセスそのものであり，その 形成過程に水素が大きく影響していることを示し ている。しかしながら実験的には，回収した試料 中の水素濃度を調べようとしても，減圧の途中で 鉄中の水素はほぼ全て吐き出されてしまうため, それを直接突き止めることは不可能であった。 そ のためこれまで鉄中に取り込まれた水素量は，X 線回折で決められた高圧下の水素化物の格子体積 から，他の金属水素化物における值を参照して見 積もられてきた[e.g. 3-6]. またその他の方法とし て，高圧下で水素が溶け込んだ溶融鉄を瞬時に減 圧・回収して, 固溶していた水素に起因する発泡 痕の大きさから水素量を見積もった研究例もある が[7], これも種々の仮定に基づいている.

これらの問題を解決するためには，水素が大き な散乱能を持っている中性子による回折が有力な 手法になる。しかし従来, 地球深部の高温高圧条 件下で中性子回折実験を行うことは技術的に困難 であった. 最近, J-PARC の物質・生命科学実験施 設 (MLF) の高圧実験専用のビームライン PLANET (BL11) [8,9]で，パルス中性子源と大型高圧プレス （通称「圧姫」，[9,10]）を組み合わせることによ り，10 万気圧千数百 ${ }^{\circ} \mathrm{C}$ での中性子その場観察を 行えるようになった。そこで筆者らは実際の地球 の状態に近い条件で鉄中の水素の直接観察を目的 とした実験を行った.

本研究では，まず，試料を高温高圧条件で長時 間安定に保つことができる高圧セル・アセンブリ を開発した (後述)。これを用いて約 $4 \mathrm{GPa}, 700^{\circ} \mathrm{C}$ を発生させ，高温高圧下でのその場観察を行い， 鉄水素化物の生成の直接観察に世界で初めて成功 した[11]. 本稿では，その内容を紹介するととも に，今後の研究の展望を述べる.

2. 高温高圧中性子回折実験に向けた高圧セル・ア センブリの開発

地球の始源物質をモデル化した試料（鉄十ケイ 酸塩 $\mathrm{MgSiO}_{3}$ +水の混合物) を高温高圧に保つと, 構成物質が脱水反応や相転移を起こして収縮する ため，試料及びそれを取り囲む圧力媒体が著しく 変形する。 そのため, 安定な高温高圧発生が困難 であった。また，高圧下で圧力媒体が大きく変形 するため, 回折信号取得の開口となるアンビルギ ヤップが狭められ，十分な回折強度が得られなか った。これらを克服するために, アンビルとセル・ アセンブリの開発を行った. Fig. 1 に開発したア ンビル及びセル・アセンブリを示す。これは，従 来のアンビルよりも直径が一回り大きく, かつ，2 段目の超硬アンビルの周りをスチールのジャケッ トでサポートしたものである.アルミ合金製のア ンビルガイドフレームには，中性子が通るパスに 穴を開けている．試料部の圧力を効率的に封止す
るためのパイロフィライト製プレガスケットは, あらかじめ $700^{\circ} \mathrm{C}$ で 15 分焼いて水分を飛ばすこ とで中性子透過率を向上させた。先端サイズが 1 辺 $10 \mathrm{~mm}$ のアンビルで, 現在約 $7 \mathrm{GPa}$ の圧力発生 を確認しており，ジャケット付きにしたことによ り, 従来に比べブローアウト（加圧バランスの崩 れに伴う試料の吹き出し）の頻度低減に成功して いる[12].

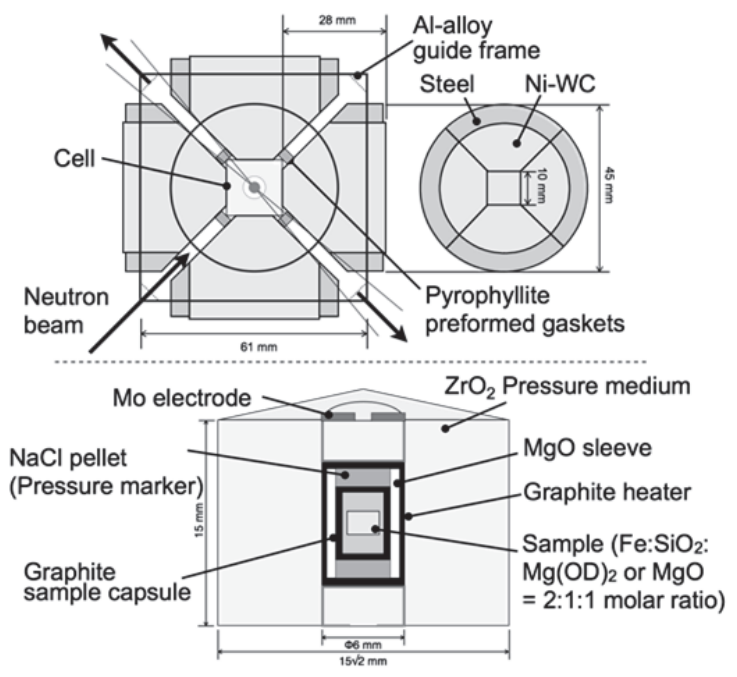

Fig. 1. Schematic of newly designed multi-anvil 6-6 assembly (upper) and cross-section of a high-pressure cell assembly (lower). The incident neutron beam with the size of $1.0 \mathrm{~mm}$ in width and $2.0 \mathrm{~mm}$ in height was introduced to sample through the gap between anvils (upper left).

試料セルは, $\mathrm{ZrO}_{2}$ キューブの圧媒体にグラファ イトヒーターを組み込んだ Fig. 1 下のような構成 になっている。出発試料はモル比で $\mathrm{Fe}: \mathrm{SiO}_{2}: \mathrm{Mg}(\mathrm{OD})_{2}=2: 1: 1$ となるように, 鉄ロッド の周りを $\mathrm{SiO}_{2}$ と $\mathrm{Mg}(\mathrm{OD})_{2}$ の混合粉末で埋めてい る.また, 水の存在の有無による違いを明らかに するために, $\mathrm{Mg}(\mathrm{OD})_{2}$ を $\mathrm{MgO}$ に変えた系も準備 し，比較実験を行った。試料を封じるカプセルの 選択には試行錯誤を繰り返し, 最も時間を費やし た。これは，これまで高温高圧実験で広く使われ てきた金属は水素による融点降下で溶融してしま うためである。 その候補として，以下の材料を検 討したが，立方晶 BN は中性子を吸収してしまう こと, また $\mathrm{MgO} や \mathrm{Al}_{2} \mathrm{O}_{3}$, 水素封止能力が高いと されている $\mathrm{NaCl}$ は高温下で試料と反応してしま うことなどの理由から最終的に，中性子をよく透 過し，かつ水をほとんど通さないグラファイトを 選択した。発生圧力は, 反応前の鉄及び試料の上 下に装填した $\mathrm{NaCl}$ の格子定数変化から状態方程 式を用いて求めた。発生温度は，事前に調べた投 入電力と発生温度の関係から求めた。実験は，圧 力を変えた 2 回のラン（Runs \#1, 3）と水を含まな い系（Run \#2）の合計 3 ラン行った. 


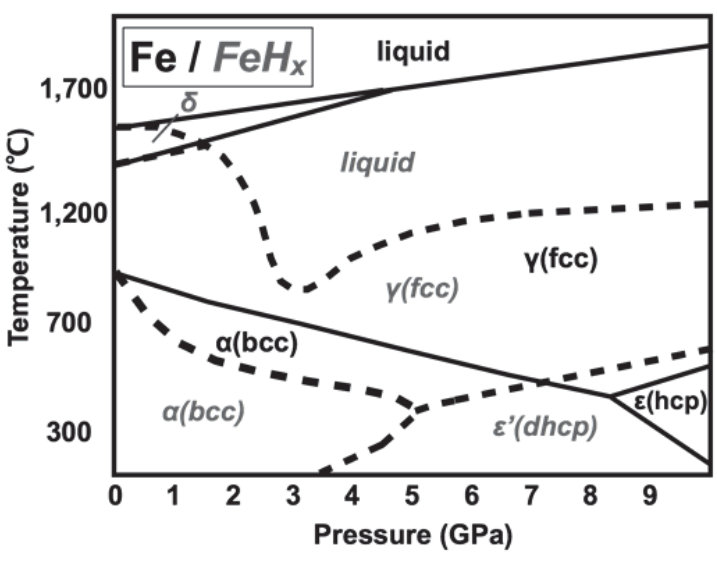

Fig. 2. Phase diagram of pure $\mathrm{Fe}$ (black) and $\mathrm{FeH}_{x}$ (gray). Phase boundaries are referred by $[3-6,13]$.
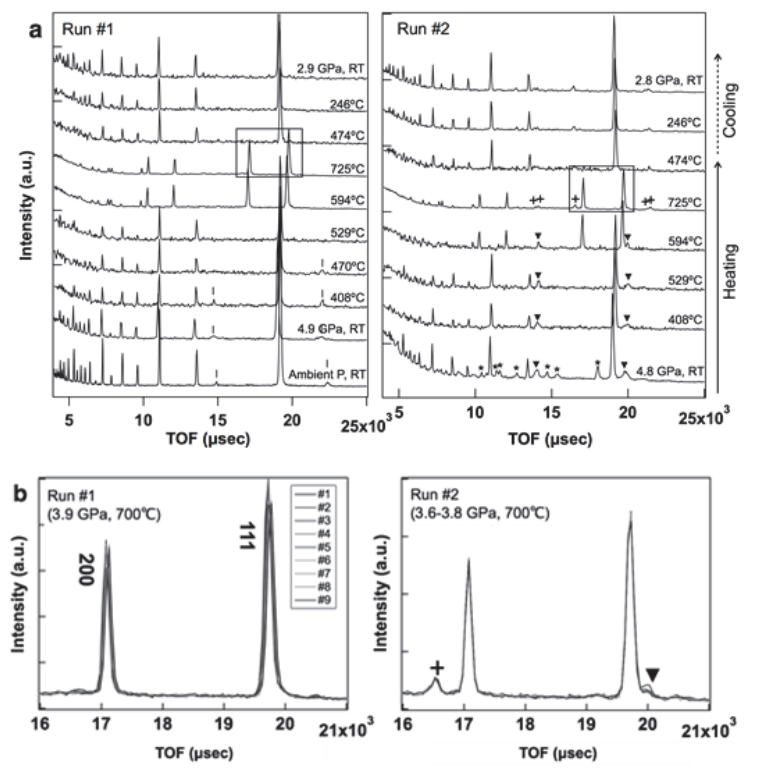

Fig. 3. (a) Powder diffraction profiles obtained at $\sim 4 \mathrm{GPa}$ and high temperatures in runs of $\# 1$ (including water) and \#2 (without water). In the run $\# 1, \operatorname{Mg}(\mathrm{OD})_{2}$ (marked with vertical bars) disappears due to dehydration at $\sim 500^{\circ} \mathrm{C}$, while in the run $\# 2$, peaks of $\mathrm{MgO}$ (triangle) remained, and then olivine (cross) appeared. A bottom profile in the run \#2 was obtained using a larger beam size to get diffractions from $\mathrm{NaCl}$ pressure marker (asterisk). In both runs, iron transformation from $b c c$ to $f c c$ phase occurred at $\sim 600^{\circ} \mathrm{C}$. (b) The 111 and 200 diffraction peaks (squared by rectangles in (a)) of $f c c$ iron or its hydride measured every hour for about 10 hours. All the peaks in the run $\# 2$ showed no changes in both the positions and the line width, while those in the run $\# 1$ shifted slightly with time.

\section{3. 実験結果}

Fig. 2 に, これまで報告されている純鉄及び水 素化鉄の相図を示寸，約 $5 \mathrm{GPa}$ まで加圧後，最高 $725^{\circ} \mathrm{C}$ までの温度範囲で段階的に温度を変えなが ら取得した回折パターンを Fig. 3 に示寸. 水を含 む系では, $500^{\circ} \mathrm{C}$ 付近で含水鉱物 $\mathrm{Mg}(\mathrm{OD})_{2}$ が脱水 分解を起こした後に, $600^{\circ} \mathrm{C}$ 弱で鉄が常圧相 $b c c$
相から高圧相である $f c c$ 相へと変化したことが確 認された. その後, 圧力と温度を約 $4 \mathrm{GPa}, 725^{\circ} \mathrm{C}$ に保ち, この $f c c$ 相の格子体積の時間変化を詳し く調べると, 徐々に体積が増加していくことが分 かった（Fig. 4)。これに対して，水を含まない系 では鉄の体積がほぼ変わらないことから，水を含 む系では鉄が水素を取り込み, 鉄水素化物 $\mathrm{FeH}_{x}$ となって体積が膨張したことが確認された。ここ で，金属中に取り込まれた水素が金属空孔と相互 作用を起こし, 格子が収縮する超多量空孔（super abundant vacancy, SAV) の形成が Fukai ら[4]によっ て報告されている。今回，格子収縮は見られてい ないので, SAV の形成は起きていないと考えられ る.

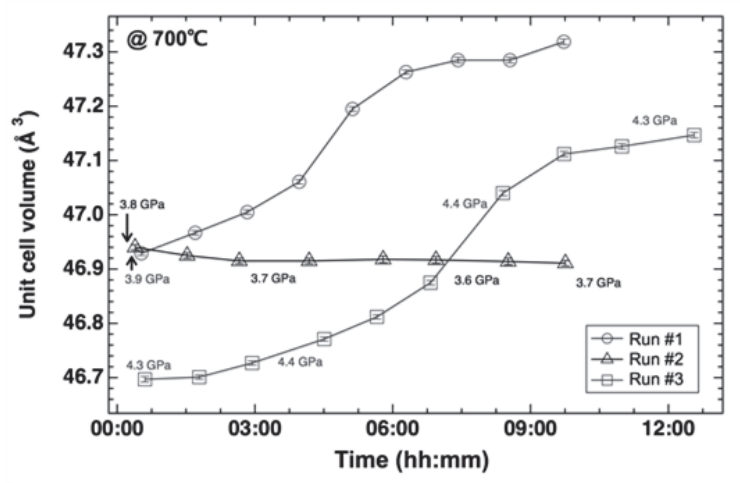

Fig. 4. Time changes of unit cell volume of $f c c$ iron while keeping at around $700^{\circ} \mathrm{C}$ for all runs. Data were collected sequentially, and each pattern was calculated using data obtained every hour. Errors were estimated based on the standard deviation of Rietveld analysis. Pressures were calculated from the unit cell volume of $\mathrm{NaCl}$ measured during the holding time and their variation was less than $\pm 0.05 \mathrm{GPa}$. In the run $\# 1$, the pressure was measured only at the beginning.

取得した鉄水素化物の中性子回折データから， リートベルト解析により水素の固溶量を求めた. 解析の際の初期構造として, 同じ PLANET でなさ れた先行研究[14,15]の, $f c c$ 鉄の $\mathrm{O}$ サイトと $\mathrm{T}$ サ イト両方に水素が取り込まれるモデルを採用した。 その結果, 温度を保持してからおよそ 10 時間後に は $x=0.19$, 重量にして約 $0.7 \mathrm{wt} \%$ の重水素が含ま れていることが分かった。これは町田ら[14]にお いて, $6.3 \mathrm{GPa}, 988 \mathrm{~K}\left(715^{\circ} \mathrm{C}\right)$ で求められた重水素 量 $2.24 \mathrm{wt} \%$ の $1 / 3$ 程度の量である. さらに, 放射 光 $\mathrm{X}$ 線を用いて約 $10 \mathrm{GPa}$ 以上で求められた值 $(x \sim 1)$ と比べても, 非常に小さな值となった. そ の理由として, 今回の実験ではグラファイトカプ セルを水素が透過した可能性以外に, (1)圧力かつ 温度条件が他と比べて低い, (2)水素化物の生成速 度が遅かったことの 2 点が挙げられる. 実際に, 熱力学計算による水素固溶量の圧力温度依存性 [16]加らも, 本研究の温度圧力条件 $\left(\sim 4 \mathrm{GPa}, 725^{\circ} \mathrm{C}\right)$ であれば, おおよそ 0.3 から 0.4 程度になるはずと 予想される. また, $f c c$ 鉄へ重水素が数分のうちに 取り込まれる様子が観察された単純な Fe-H系[14] 
と比較して，含水鉱物の脱水によりできた水によ る水素化物生成は異なる反応過程を経ているため に，反応が平衡に至るまでに数時間もかかったと 考えられる. 反応の進行が遅い要因は, 回収試料 の SEM 画像（Fig. 5）からも示唆される. 水を含 む試料系にのみ，鉄中に溶け込んでいた水素が減 圧中に発泡して抜けた跡が粒界に沿って見られた。 また $\mathrm{SiO}_{2}$ と $\mathrm{MgO}, \mathrm{Fe}$ が反応してできたオリビン $(\mathrm{Fe}, \mathrm{Mg})_{2} \mathrm{SiO}_{4}$ と鉄との境界部分に酸化鉄 $\mathrm{FeO}$ の薄 い層が確認された。このことから，以下のような 水と鉄の反応により $\mathrm{FeO}$ と $\mathrm{FeH}_{x}$ が生成される際 に，鉄の周囲に $\mathrm{FeO}$ の皮膜ができ，反応の進行が 阻害されたと結論づけられる.

$$
2 \mathrm{Fe}+\mathrm{H}_{2} \mathrm{O} \rightarrow \mathrm{FeO}+\mathrm{FeH}_{x}+(1-x / 2) \mathrm{H}_{2} \uparrow
$$

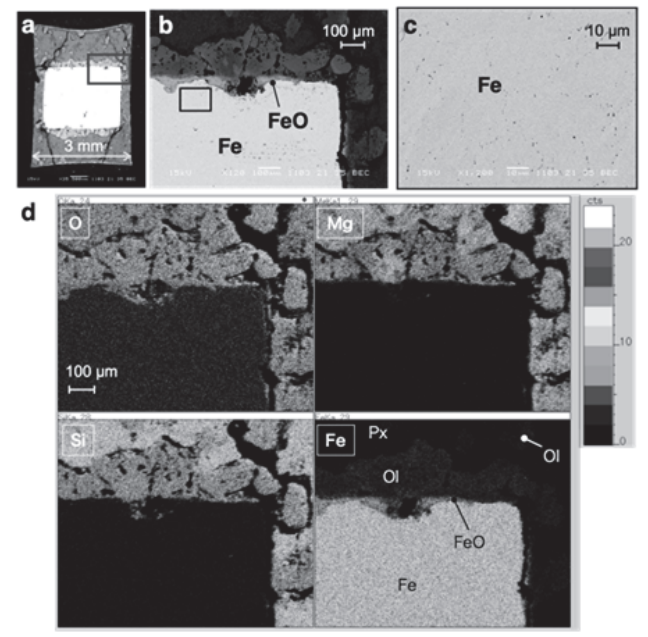

Fig. 5. Results of SEM analysis on the recovered sample including water (Run \#3). (a-c) Electron images of sample with different magnification, and (d) elemental maps on $\mathrm{O}, \mathrm{Si}, \mathrm{Mg}$ and $\mathrm{Fe}$. A thin $\mathrm{FeO}$ layer was found on the surface of the iron in Fig. 5b, as well as small vacant holes in Fig. 5c. Several silicates of olivine $(\mathrm{Ol})$ and pyroxene $(\mathrm{Px})$ containing iron atoms were observed in the area where the mixture of $\mathrm{Mg}(\mathrm{OD})_{2}$ and $\mathrm{SiO}_{2}$ was initially placed. Olivine containing rich iron preferentially located close to the iron.

\section{4. 地球科学的考察と今後の展開}

本研究の結果から, 高温高圧下で含水鉱物の脱 水が起きて水が供給されれば， $700^{\circ} \mathrm{C}$ 程度という 比較的低い温度でも固体の鉄に水素が溶け込むこ とが明らかになった。このことから，原始地球に おいて始源物質が集積し温度が上がっていく初期 の段階で，水素はすでに鉄へと溶け込み始めてい たことが示唆される．現在のコアに存在する可能 性がある他の軽元素は, より高温で生じる溶融鉄 でないと溶けこまないため, 地球進化の初期過程 において他の軽元素よりも水素が先駆けて固体鉄 に溶け込んでいき鉄水素化物となり，その後によ り高温で溶融した鉄水素化物が他の軽元素を取り 込みながら中心へと沈んでいき，コアを形成した と考えられる

最後に，コアに取り込まれた軽元素の問題に向
けた今後の展望を述べる.コアーマントルの分離 過程や他の軽元素の溶融鉄への溶解の可能性をよ り詳しく検証していくためには，純鉄とケイ酸塩 の系ばかりではなく，水素化した鉄とケイ酸塩間 での軽元素の分配を調べることが重要になる．本 研究の結果は, 地球コアにおける軽元素の謎につ いて，これからの研究の展開に大きな示唆を与え るものであると捉えている. PLANETを用いた中 性子回折実験のメリットを生かして, 鉄水素化物 中への他軽元素の高温高圧下での反応挙動の探索 は, 現在も進行中である.

\section{5. 終わりに}

著者らは PLANET のビームラインの立上げ時 から関わっており，大型プレスを用いた成果とし て本研究は大変感慨深い. 今後も引き続き, PLANET での中性子実験から, 時間をも超えて地 球深部の謎に迫っていきたいと考えている.また, 本研究で開発された高圧実験技術に加えて, さら なる実験・測定技術の改良が進み, 高圧下での中 性子その場観察実験がより汎用的なものになるこ とで, 物質科学から地球科学に至る多岐分野の二 ーザーが取り掛かりや寸くなることを期待したい.

\section{謝辞}

舟越賢一氏, 阿部淳氏, 町田真一氏（総合科学 研究機構）には, 実験に際して多大なサポートを 受けました。 また青木勝敏氏 (東京大学), 町田晃 彦氏, 齋藤宽之氏（量子科学技術研究開発機構） には貴重なコメントをいただきました。ここに深 く感謝いたします. 本研究の中性子回折実験は, J-PARC MLF 実験課題（2013B0034，2014A0049, 2014B0044）として, 科学研究費補助金 基盤研究 A（研究課題番号 25246037）の下で実施されまし た.

\section{参考文献}

[1] J. P. Poirier, Phys. Earth Planet. Inter. 85, 319-337 (1994).

[2] Y. Fukai, Nature 308, 174 (1984).

[3] V. E. Antonov, I. T. Belash, E. G. Ponyatovsky, Scr. Metal. 16, 203-208 (1982).

[4] Y. Fukai, K. Mori, H. Shinomiya, J. Alloys Compd. 348, 105-109 (2003).

[5] K. Sakamaki, E. Takahashi, Y. Nakajima, Y. Nishihara, K. Funakoshi, T. Suzuki, Y. Fukai, Phys. Earth Planet. Int. 174, 192 (2009).

[6] T. Yagi, T. Hishinuma, Geophys. Res. Lett. 22, 1933-1936 (1995).

[7] T. Okuchi, Science 278, 1781-1784 (1997).

[8] T, Hattori, A. Sano-Furukawa, H. Arima, K. Komatsu, A. Yamada, Y. Inamura, T. Nakatani, Y. Seto, T. Nagai, W. Utsumi, T. Iitaka, H. Kagi, Y. Katayama, T. Inoue, T. Otomo, K. Suzuya, T. Kamiyama, M. Arai, T. Yagi, Nucl. Instrum. Methods Phys. Res. A 780, 55-67 (2015). 
[9] 服部高典，波紋 25, 231-237 (2015).

[10] A. Sano-Furukawa, T. Hattori, H. Arima, A. Yamada, S. Tabata, M. Kondo, A. Nakamura, H. Kagi, T. Yagi, Rev. Sci. Instrum. 85, 113905 (2014).

[11] R. Iizuka-Oku, T. Yagi, H. Gotou, T. Okuchi, T. Hattori, A. Sano-Furukawa, Nature Commun. 8, 14096 (2017).

[12] 山田明寛ら，高圧力の科学と技術 26, 99-107 (2016).

[13] S. Klotz, Y. Le Godec, Th. Strässle, U. Stuhr, Appl. Phys. Lett. 93, 091904 (2008).

[14] A. Machida, H. Saitoh, H. Sugimoto, T. Hattori, A. Sano-Furukawa, N. Endo, Y. Katayama, R. Iizuka, T. Sato, M. Matsuo, S. Orimo, K. Aoki, Nature Commun. 5, 5063 (2014).

[15] 青木勝敏ら，波紋 25, 26-31 (2015).

[16] H. Sugimoto, Y. Fukai, Acta Metal. Mater. 40, 2327-2336 (1992). 